\title{
The Positive Predictive Value of Onconeural Antibody Testing: A Retrospective Review
}

\author{
Adrian Budhram, Michael W. Nicolle, Liju Yang
}

\begin{abstract}
Paraneoplastic syndromes (PNS) are immune-mediated neurologic diseases that occur as an indirect effect of malignancy, and can be challenging to diagnose. Onconeural antibodies have a greater than $95 \%$ association with cancer, and their presence in a patient with neurologic symptoms is reportedly highly indicative of PNS. However, we performed a single-centre retrospective review to determine the positive predictive value of onconeural antibody testing, and found it to be concerningly low (39\%). Recognising the limitations of onconeural antibody testing is critical to ensure accurate test interpretation, avoid unnecessary repeated malignancy screening and prevent the use of potentially hazardous immunotherapy.
\end{abstract}

RÉSUMÉ: Analyse rétrospective de la valeur prédictive positive des anticorps onconeuronaux. Les syndromes paranéoplasiques sont des maladies neurologiques à médiation immunitaire qui résultent indirectement du caractère malin de certains cas de cancer. Ils peuvent aussi être difficiles à diagnostiquer. L'association entre des cas de cancer et les anticorps onconeuronaux dépasse les $95 \%$. La présence de ces anticorps chez un patient montrant des symptômes neurologiques semble être fortement révélatrice de la présence de syndromes paranéoplasiques. Dans un seul établissement hospitalier, nous avons quand même effectué une analyse rétrospective afin de déterminer la valeur prédictive positive (VPP) des anticorps onconeuronaux. Cette dernière s'est révélée faible (39\%), ce qui constitue une source de préoccupation. À cet égard, il est essentiel de reconnaître les limites de ce type de test afin d'en assurer une interprétation exacte. Il est aussi important d'éviter un dépistage répété et inutile de cas de cancer malin et d'empêcher l'utilisation d'immunothérapie potentiellement risquée.

Keywords: Paraneoplastic conditions, Paraneoplastic encephalomyelitis, Neuroimmunology, Neuro-oncology—medical

doi:10.1017/cjn.2018.74

Can J Neurol Sci. 2018; 45: 577-579

Paraneoplastic neurologic syndromes (PNS) are immunemediated diseases of the nervous system that occur as an indirect effect of malignancy. Patients with these syndromes often harbour onconeural antibodies, which target intracellular neural antigens and have a greater than $95 \%$ association with cancer. ${ }^{1}$ This is in contrast to other autoantibodies that may be found in either paraneoplastic or primary autoimmune disease, bind to cell surface or synaptic proteins and are less predictive of malignancy (e.g. anti-voltage-gated calcium channel antibodies in patients with Lambert-Eaton myasthenic syndrome, which are paraneoplastic in only $50 \%-60 \%$ of cases). ${ }^{2}$ The presence of onconeural antibodies in a patient with neurologic symptoms reportedly strongly indicates the presence of a PNS, leading to extensive malignancy screening and consideration of immunotherapy. In 2015, London Health Sciences Centre (LHSC) became one of the first centres in Canada to perform in-house onconeural antibody testing. However, on informal review of this assay we noticed a seemingly high number of positive results compared with previous reports. As such, we performed a retrospective review to determine the positive predictive value (PPV) of onconeural antibody testing in the diagnosis of PNS.

We identified all patients who underwent serum onconeural antibody panel testing at LHSC from 2015 to 2017. All samples were analysed for onconeural antibodies (anti-Hu, Yo, Ri, Ma2, CV2 and amphiphysin) by two different methods: indirect immunofluorescence (IFA) on primate cerebellar and intestinal tissue with BIOCHIP Mosaics for Neurology and immunoblot (IB) with EUROLINE Neuronal Antigens Profile 2. The IFA was interpreted as negative or positive for a specific onconeural antibody fluorescence pattern, whereas the IB was read as negative or weakly (1+), moderately (2+) or strongly (3+) positive; an onconeural antibody was reported as positive if either IFA or IB was positive. A full chart review of the clinical history, examination, serum and cerebrospinal fluid testing, neuroimaging and electrophysiologic studies was performed on all patients who had a positive onconeural antibody result. The presence of an onconeural antibody was considered a false positive (FP) only if no malignancy was diagnosed and an alternative aetiology for the patient's neurologic symptoms was identified

From the Department of Clinical Neurological Sciences, London Health Sciences Centre, London, Ontario, Canada (AB, MWN); Department of Pathology and Laboratory

Medicine, London Health Sciences Centre, London, Ontario, Canada (LY).

Received January 14, 2018. Final Revisions Submitted January 14, 2018. Date OF ACCEPTANCE APRIL 18, 2018.

Correspondence to: Adrian Budhram, Clinical Neurological Sciences, University Hospital, 339 Windermere Road, London, ON N6A 5A5, Canada. Email: adrian. budhram@lhsc.on.ca 


\section{Table 1: Neurologic syndromes in patients with para- neoplastic syndromes (PNS) and non-paraneoplastic neurological syndromes (NPNS)}

\begin{tabular}{|c|c|}
\hline & Number of patients with diagnosis \\
\hline \multicolumn{2}{|l|}{$\begin{array}{l}\text { Neurologic syndromes in patients } \\
\text { with PNS }\end{array}$} \\
\hline Encephalitis & $\begin{array}{l}4 \text { ( } 2 \text { limbic encephalitis, } 2 \text { limbic and } \\
\text { brainstem encephalitis) }\end{array}$ \\
\hline Sensory neuropathy & $\begin{array}{l}3 \text { ( } 2 \text { sensory neuronopathy, } 1 \text { small-fibre } \\
\text { sensory neuropathy) }\end{array}$ \\
\hline Basal ganglia syndrome & 1 (rapid-onset dystonia-parkinsonism) \\
\hline Cerebellar syndrome & 1 (progressive ataxic syndrome) \\
\hline \multicolumn{2}{|l|}{$\begin{array}{l}\text { Causes of neurological syndromes in } \\
\text { patients with NPNS }\end{array}$} \\
\hline Neurodegenerative & $\begin{array}{l}4 \text { (3 Parkinson's-plus syndrome, } 1 \\
\text { Alzheimer's disease) }\end{array}$ \\
\hline Toxic/metabolic encephalopathy & $\begin{array}{l}3 \text { (1 polypharmacy, } 1 \text { hepatic encephalopathy } \\
1 \text { multiple electrolyte derangements) }\end{array}$ \\
\hline Neuromyelitis optica & $\begin{array}{l}2 \text { (Anti-AQ4-ab + longitudinally extensive } \\
\text { transverse myelitis) }\end{array}$ \\
\hline Orthostatic intolerance & $\begin{array}{c}2 \text { (1 postural orthostatic tachycardia } \\
\text { syndrome, } 1 \text { labile hypertension) }\end{array}$ \\
\hline Idiopathic focal-onset epilepsy & 2 ( 1 temporal lobe onset, 1 frontal lobe onset) \\
\hline Structural & 1 (lumbar stenosis) \\
\hline
\end{tabular}

clinically or pathologically. These patients were categorised as having non-paraneoplastic neurological syndromes (NPNS). The presence of an onconeural antibody was otherwise considered a true positive (TP), and these patients were classified as having a PNS.
Using these data, the PPV of onconeural antibody testing for PNS was then calculated.

On review, 308 patients were identified who underwent onconeural antibody testing at our institution. Of these patients, 23 (7.5\%) tested positive for an onconeural antibody (anti-Ma2 $=14$, amphiphysin $=5, \mathrm{CV} 2=3, \mathrm{Hu}=1, \mathrm{Yo}=1$; one patient tested positive for both anti-Ma2 and CV2). Only 39\% of these patients were positive by IFA, whereas $96 \%$ were positive by IB; $35 \%$ of patients were positive by both IFA and IB. The mean age was 59 years (range: $21-87$ ), and 65\% were men. Nine of 23 patients with various neurologic syndromes were considered TP, and categorised as having a PNS (see Table 1). An associated tumour was identified in five of these patients: four with anti-Ma2 antibodies (Hodgkin's lymphoma, testicular teratoma, papillary thyroid carcinoma/ medullary microcarcinoma and bronchoalveolar carcinoma) and one with anti-Hu antibodies (small-cell lung carcinoma). Out of the 23 patients, 14 were considered FP, with no malignancy found and an alternative diagnosis established clinically or pathologically; these patients were categorised as NPNS (see Table 1). The calculated PPV for onconeural antibody testing was 39\%. When comparing PNS with NPNS, there was no significant difference in terms of age, sex, smoking history, symptom duration, antibody positivity, percentage positive by IFA, IB or both IFA and IB (see Table 2). However, only two patients were positive for both an onconeural antibody by IFA and had a strongly positive IB, both of whom were considered TP and classified as having a PNS.

The Euronetwork PNS diagnostic criteria considers the presence of a well-characterised onconeural antibody sufficient for the diagnosis of PNS, even in patients with non-classical neurologic presentations and no malignancy. ${ }^{3}$ It is therefore challenging to evaluate the diagnostic accuracy of onconeural antibody testing owing to incorporation bias, which occurs when the diagnostic

Table 2: Patient characteristics and onconeural antibodies identified

\begin{tabular}{|c|c|c|c|}
\hline & PNS $(n=9)$ & NPNS $(n=14)$ & $p$-Value \\
\hline \multicolumn{4}{|l|}{ Patient characteristics } \\
\hline Age (mean) & 58 & 60 & $>0.05$ \\
\hline Male (\%) & $67 \%$ & $64 \%$ & $>0.05$ \\
\hline Ever-smoker (\%) & $56 \%$ & $36 \%$ & $>0.05$ \\
\hline Time from symptom onset to onconeural antibody testing (years) & 2.9 & 2.6 & $>0.05$ \\
\hline Time from symptom onset to last follow-up (years) & 4.0 & 3.5 & $>0.05$ \\
\hline \multicolumn{4}{|l|}{ Onconeural antibodies identified* } \\
\hline Anti-Ma2 (\%) & $56 \%$ & $64 \%$ & $>0.05$ \\
\hline Anti-amphiphysin (\%) & $11 \%$ & $29 \%$ & $>0.05$ \\
\hline Anti-CV2 (\%) & $22 \%$ & $7 \%$ & $>0.05$ \\
\hline Anti-Hu (\%) & $11 \%$ & $0 \%$ & $>0.05$ \\
\hline Anti-Yo (\%) & $0 \%$ & $7 \%$ & $>0.05$ \\
\hline Anti-Ri (\%) & $0 \%$ & $0 \%$ & $>0.05$ \\
\hline Positive by IFA (\%) & $33 \%$ & $43 \%$ & $>0.05$ \\
\hline Positive by IB $(\%)^{* *}$ & $100 \%$ & $93 \%$ & $>0.05$ \\
\hline Positive by IFA and IB (\%) & $33 \%$ & $36 \%$ & $>0.05$ \\
\hline
\end{tabular}

IB = immunoblot; IFA = indirect immunofluorescence; NPNS = non-paraneoplastic neurological syndromes; PNS = paraneoplastic syndromes

*One patient was positive for both anti-Ma2 and CV2 antibodies.

**Of the nine patients with PNS who had positive onconeural antibodies by IB, 4 were $1+$ positive, 3 were $2+$ positive and 2 were $3+$ positive. Of the 13 patients with NPNS who had positive onconeural antibodies by IB, 10 were $1+$ positive, 2 were $2+$ positive and 1 was $3+$ positive. 
test under study is incorporated into the diagnostic criteria of the disease. ${ }^{4}$ In our retrospective review of onconeural antibody testing, we found that $7.5 \%$ of patients tested had a reported positive result. This is in contrast to previous studies that have found onconeural antibodies in only $1 \%-2 \%$ of patients screened for suspected PNS. ${ }^{5,6}$ Although this could theoretically be because of improved patient selection at our institution, the findings of our study are concerning for a high proportion of FP. Interestingly, anti-Ma2 accounted for the majority (61\%) of all positive results in our review, followed by anti-amphiphysin (22\%) and anti-CV2 (13\%). This is in contrast to previously reported onconeural antibody frequencies in the largest database on PNS, wherein the most frequently reported onconeural antibody was anti-Hu (39\%) followed by anti-Yo (13\%). ${ }^{7}$

The discrepancies between our findings and previous studies may at least partially be due to the fact that the majority of our reported positive onconeural antibody test results were positive by IB but negative by IFA. This is in contrast to the term "wellcharacterised onconeural antibodies" as defined in the Euronetwork PNS diagnostic criteria, which requires initial positivity by immunohistochemistry followed by positive immunoblotting to confirm antibody specificity. ${ }^{3}$ It has been recommended not to rely solely on IB for the identification of onconeural antibodies, without confirmation by another method such as IFA. ${ }^{1,8}$ This is of particular relevance as onconeural antibody testing becomes available to generalist laboratories, which may lack the expertise required to interpret IFA and therefore overly rely on IB when reporting a positive result. Although in our study there was no statistically significant difference in the number of patients who were positive by both IFA and IB when comparing PNS with NPNS, it is worth noting that only two patients were both positive by IFA and had a strongly positive IB result. Both of these patients had a malignancy identified and were classified as TP, suggesting that concordant positivity by IFA and strong positivity by IB remains highly indicative of PNS.

Our study has several limitations. Owing to its retrospective nature, there were no criteria used to select who underwent onconeural antibody testing. Performing a test on patients who are highly unlikely to have a positive result may lower the PPV of the test, which decreases alongside the prevalence of a disease in a tested population. Our study reflects clinical practice, however, as healthcare providers frequently order onconeural antibody testing even in patients with atypical neurologic presentations once an autoimmune or paraneoplastic aetiology is entertained. Another limitation to our study is that we only reviewed the charts of patients with positive onconeural antibody testing. This precludes calculation of sensitivity, specificity or negative predictive value of this test, which all require separating true negative (TN) from false negative (FN) results. It bears emphasising, however, that patients with PNS may have non-classical neurologic presentations, and that onconeural antibody detection may precede the diagnosis of an occult malignancy by years. As such, even in a patient with neurologic symptoms that are atypical for a PNS and no identified malignancy, it remains challenging to assert that a negative onconeural antibody panel is a TN (i.e. the patient truly does not have a PNS). Conversely, a patient may have a syndrome that is clearly paraneoplastic but not typically associated with onconeural antibodies, such as a young woman with opsoclonus-myoclonus syndrome and an ovarian teratoma. ${ }^{9}$ Although her onconeural antibody panel would probably be negative in the presence of a PNS, it would seem inappropriate to consider this result a FN.

Given these difficulties in distinguishing between TN and FN, and the fact that our primary concern was a seemingly high number of positive onconeural antibody test results, we focused on distinguishing between TP and FP in order to calculate the PPV. The PPV of onconeural antibody testing has a major impact on clinical decision-making, as it represents the percentage of patients with a positive test result who actually have PNS. Owing to the lack of a non-pathologic diagnostic gold standard for PNS, we opted to exercise caution in determining which patients we classified as NPNS, by requiring that no malignancy be present and that an alternative diagnosis be identified. Although this method probably resulted in patients with NPNS being classified as PNS simply because of the lack of an alternative diagnosis, it avoids overestimation of FP and artificial lowering of the PPV. Despite this conservative approach, the calculated PPV of onconeural antibody testing for PNS in our study was only $39 \%$. Our study suggests that the PPV of onconeural antibody testing for PNS may be lower than appreciated by healthcare providers. In particular, onconeural antibody detection by immunoblotting alone, without confirmatory testing by a second assay such as IFA, should be viewed critically. Recognising the potential diagnostic pitfalls of onconeural antibody testing is essential to avoid unnecessary repeated malignancy screening, inappropriate administration of immunotherapy and delayed identification of correct alternative diagnoses.

\section{Disclosures}

The authors declare that they have nothing to disclose.

\section{Statement of Authorship}

$\mathrm{AB}$ analysed the data and drafted the manuscript. MWN reviewed the manuscript for intellectual content. LY analysed the data and reviewed the manuscript for intellectual content.

\section{REFERENCES}

1. Raspotnig M, Vedeler CA, Storstein A. Onconeural antibodies in patients with neurological symptoms: detection and clinical significance. Acta Neurol Scand Suppl. 2011;124(191):83-8.

2. Nicolle MW. Myasthenia gravis and Lambert-Eaton myasthenic syndrome. Contin Lifelong Learn Neurol. 2016;22(6): 1978-2005.

3. Graus F, Delattre JY, Antoine JC, et al. Recommended diagnostic criteria for paraneoplastic neurological syndromes. J Neurol Neurosurg Psychiatry. 2004;75(8):1135-40.

4. Worster A, Carpenter C. Incorporation bias in studies of diagnostic tests: how to avoid being biased about bias. CJEM. 2008;10 (2): $174-5$.

5. Karim AR, Hughes RG, Winer JB, Williams AC, Bradwell AR. Paraneoplastic neurological antibodies: a laboratory experience. Ann N Y Acad Sci. 2005;1050(1):274-85.

6. Pittock SJ, Kryzer TJ, Lennon VA. Paraneoplastic antibodies coexist and predict cancer, not neurological syndrome. Ann Neurol. 2004;56(5):715-9.

7. Giometto B, Grisold W, Vitaliani R, et al. Paraneoplastic neurologic syndrome in the PNS Euronetwork database. Arch Neurol. 2010;67(3):330.

8. Zoccarato M, Gastaldi M, Zuliani L, et al. Diagnostics of paraneoplastic neurological syndromes. Neurol Sci. 2017;38 (Suppl 2):237-42.

9. Armangue T, Titulaer MJ, Sabater L, et al. A novel treatmentresponsive encephalitis with frequent opsoclonus and teratoma. Ann Neurol. 2014;75(3):435-41. 